\title{
PENGARUH PERILAKU PENGENDARA TERHADAP KECELAKAAN PEJALAN KAKI-SEPEDA MOTOR
}

\author{
The Influence of Rider Behaviour to Pedestrian-Motorcycle Accident
}

\author{
Febriane Paulina Makalew \\ Jurusan Teknik Sipil \\ Politeknik Negeri Manado \\ Jl. Politeknik Buha Mapanget \\ Sulawesi Utara \\ fmakalew@yahoo.com
}

\author{
Bambang Widodo \\ Jurusan Teknik Sipil \\ Politeknik Negeri Manado \\ J1. Politeknik Buha Mapanget \\ Sulawesi Utara \\ bambangpwidodo@yahoo.com
}

\author{
Muhammad Isran Ramli \\ Departemen Teknik Sipil \\ Universitas Hasanuddin \\ Jl. Poros Malino Km. 6, Gowa \\ Sulawesi Selatan \\ isranramli@unhas.ac.id
}

\begin{abstract}
Accident within rider and pedestrian is increased during the last five years period. Conflict street users occur due to factors such as behavior and facility available. This research aims to analyze rider behavior and their influence on the pedestrian-motorcycle accident. The research location is North Sulawesi Province with the distribution of the questionnaire. Accident data reference is used to evaluate factors influence the accident. Research result shows differences and similarity judgment for rider behavior in urban dan rural area. Majority choice show rider understanding of aspects in reducing the number of accidents. Differences of location have a different facility available and the use of traffic line for rider and pedestrian. Although it is not a majority, a choice against factors to reduce accident can be fatal to the user. However, this option needs further research related to factors to influence such a choice. It is crucial to put safety pedestrian and rider into priority by strong regulation.
\end{abstract}

Keywords: Accident, rider behavior, pedestrian, urban, rural

\begin{abstract}
Abstrak
Kecelakaan yang melibatkan pejalan kaki dan sepeda motor meningkat dalam kurun waktu lima tahun terakhir. Konflik pengguna jalan terjadi disebabkan berbagai faktor seperti perilaku dan ketersediaan fasilitas. Penelitian ini bertujuan untuk menganalisa perilaku pengendara dan pengaruhnya terhadap kecelakaan pejalan kaki-sepeda motor. Lokasi penelitian di provinsi Sulawesi Utara dengan metode penyebaran kuisioner. Rujukan data kecelakaan digunakan untuk mengevaluasi faktor yang mempengaruhi terjadinya kecelakaan. Hasil penelitian menunjukkan adanya perbedaan dan persamaan penilaian yang menggambarkan perilaku pengendara di area perkotaan dan perdesaan. Mayoritas penilaian menunjukkan pemahaman terhadap aspek-aspek yang dapat mengurangi kecelakaan. Perbedaan lokasi kecelakaan memiliki perbedaan fasilitas yang tersedia dan penggunaan jalur lalu lintas bagi pengendara dan pejalan kaki. Meskipun bukan mayoritas pilihan tapi pertentangan akan faktor untuk mengurangi kecelakaan dapat berakibat fatal. Namun hal ini perlu diteliti lebih lanjut faktor yang mempengaruhi pilihan tersebut. Penting sekali untuk mulai mengutamakan keselamatan pejalan kaki dan pengendara sepeda motor dengan peraturan yang tegas..
\end{abstract}

Kata Kunci: Kecelakaan, perilaku pengendara, pejalan kaki, perkotaan, perdesaan

\section{PENDAHULUAN}

Penggunaan sepeda motor sebagai sarana transportasi mendominasi pilihan moda transportasi bersamaan dengan pilihan utama bagi masyarakat untuk menggunakan jalur pejalan kaki pada jarak tujuan yang bisa dijangkau dengan berjalan kaki. Pada area dimana terdapat sejumlah pengendara dan pejalan kaki baik yang menggunakan jalur jalan secara bersama maupun terpisah kecelakaan antara pengendara dan pejalan kaki sering terjadi. Ariffin dkk (2017), menemukan lima faktor yang berhubungan dengan luka akibat 
kecelakaan antara sepeda motor dan pejalan kaki yaitu usia, lokasi tubuh yang luka, kecepatan, geometri jalan dan pencahayaan. Teknologi yang menjamin keamanan sepeda motor perlu ditingkatkan untuk mengantisipasi kecelakaan dengan pejalan kaki. Selanjutnya, meningkatnya kecelakaan bagi pengendara dan pejalan kaki didominasi oleh pengendara tidak menggunakan helm pengaman terutama pada pelajar. Murahnya harga sepeda motor dan tidak optimalnya transportasi bagi pelajar menyebabkan banyaknya pengguna sepeda motor (Solagberu dkk, 2006). Perlunya peraturan yang mengharuskan penggunaan helm bagi pengendara dan ketersediannya dengan harga terjangkau dan sesuai dengan cuaca di Nigeria yang panas dapat menurunkan jumlah luka yang fatal saat terjadi kecelakaan (ibid). kecelakaan dan luka serius banyak mendominasi pengendara dan pejalan kaki (Indriani, 2015). Kecelakaan terbanyak adalah kecelakaan motor dan pejalan kaki dimana pengendara adalah laki-laki, usia 18-25 tahun dan pada waktu siang sampai sore hari (Bolla. 2014). Bahaya kecelakaan yang mengakibatkan kematian dan luka serius pada kedua pengguna jalan memerlukan perhatian khusus terutama evaluasi faktor yang menyebabkan kecelakaan terjadi. Diharapkan tabrakan pejalan kaki dan pengendara dapat dikurangi dan dihindarkan. Penelitian ini bertujuan untuk menganalisa perilaku pengendara dan pengaruhnya terhadap kecelakaan pejalan kaki-sepeda motor.

\section{KAJIAN LITERATUR}

Faktor yang berpengaruh pada kemungkinan kematian dan cacat akibat kecelakaan adalah kondisi pengendara, tipe kendaraan, usia pejalan kaki antara 26 sampai 65 tahun dan 65 tahun ke atas, akhir minggu, kondisi pencahayaan, karakteristik jalan, permukaan jalan, kelas jalan dan kecepatan kendaraan (Chen dkk, 2019).

Untuk meningkatkan keamanan pengguna dalam hal kondisi fisik, penelitian dilakukan berhubungan dengan disain jalur sepeda motor dan kondisi permukaan. Jalur sepeda motor merupakan faktor yang penting dalam upaya meningkatkan keselamatan pengendara dan pejalan kaki. Husain dkk (2005) mempelajari jalur sepeda motor dimana komponen penting dalam sistim lalu lintas sepeda motor adalah disain, ketersediaan ruang, perilaku pengendarai dan pengaruh satu terhadap yang lain. Pengukuran jalur sepeda motor memerlukan ruang untuk saling berpapasan dan kebebasan mementukan kecepatan kendaraan dimana lebar jalur harus lebih dari 1,7 m (ibid). Le dkk (2016), mengevaluasi hubungan antara sepeda motor dan keselamatan serta disain jalur sepeda motor dimana tipe jalur terdiri dari jalur khusus sepeda motor dan pemisahan jalur dengan menandai jalur sepeda motor. Kecepatan sepeda motor pada jalur khusus dapat lebih dari $60 \mathrm{~km} / \mathrm{jam}$ sedangkan pada jalur yang dipisahkan dengan tanda sebaiknya memiliki kecepatan kurang dari $60 \mathrm{~km} / \mathrm{jam}$. Sedangkan, Bella dkk (2012) menganalisa pengaruh permukaan aspal pada dinamika perilaku pengendara dimana terdapat skenario yang berbeda terhadap variabel radius kurva horizontal, koefisien gesekan, kecepatan sepeda motor dan tindakan pengereman. Dengan metode ini area aman dan tidak aman bagi pengendara ditentukan.

Dalam hubungan dengan perilaku, penelitian berkaitan tiga hal penting bagi pengendara muda adalah mencari sensasi, bersahabat dan tidak sabar Wong dkk (2010). Faktor evaluasi adalah kecepatan, kekawatiran, kemungkinan kecelakaan, efisien, ketidaksukaan mengambil resiko, kekawatiran, kemarahan, kesenangan, kemanusiaan, kurang memiliki aturan (Machin dkk, 2008). Terdapat perbedaan antara pengendara di area perkotaan dan perdesaan. Perbedaan resiko perilaku pengendara di area urban dan rural dimana anak muda di daerah rural memiliki resiko lebih tinggi daripada di daerah perkotaan (Eiksund 
2009). Finch dkk (1994) menunjukkan perbedaan kecepatan di area urban dan rural dimana area rural lebih cepat daripada urban.

Dalam kaitan dengan pelangaran penelitian oleh Demir dkk (2019) membandingkan model theory of planned behavior (TPB) dan prototype willingness model (PWM) untuk mengetahui pelanggaran pejalan kaki yang penting bagi masalah keselamatan lalu lintas. Pelanggaran pejalan kaki yang membahayakan banyak terjadi karena kemauan daripada keinginan untuk berhati-hati. Selanjutnya, Cheng dkk (2015), mengidentifikasi hubungan antara pelanggaran mengemudi dan persepsi akan resikonya dimana kedua faktor ini merupakan prediksi yang signifikan pada kecelakaan. Pengendara yang terlibat dalam kecelakaan menunjukkan perilaku yang lebih agresif dan pelanggaran dalam mengendarai sepeda motor (ibid). Tetapi hasil penelitian Cheng dkk (2015) yang menunjukkan bahwa pengendara memiliki persepsi lebih rendah dalam hal resiko karena faktor lingkungan bertolak belakang dengan evaluasi pentingnya jalur pengendara dan kondisi jalan.

Penggunaan kuisioner untuk mengetahui perilaku pengendara juga dilakukan sebagai bagian dari peningkatan keamanan di jalan terutama yang sesuai dengan karakter lokal. Motevalian dkk (2011), meninjau kembali kuisioner perilaku pengendara sepeda motor atau Motorcycle Rider Behavior Questionnaire (MRBQ) dan disesuaikan dengan kondisi daerah setempat dimana terdapat item yang dihapus dan ditambahkan. Evaluasi ini dilakukan dengan menggunakan Buss-Perry Aggression Questionnaire pada sejumlah pengendara. Item yang dihapus diantaranya penggunaan sepatu boot, pakaian pelindung, sarung tangan dan pakaian yang dapat memancarkan sinar. Sedangkan item yang ditambahkan adalah mengendarai pada arah yang berlawanan dan menggunakan telepon genggam.

\section{METODOLOGI}

Metode penelitian ini adalah kuisioner bagi pengendara sebanyak 295 responden di provinsi Sulawesi Utara. serta evaluasi data kecelakaan dan penyebabnya. Selanjutnya dilakukan analisa mengenai faktor yang menyebabkan kecelakaan pejalan kaki dan sepeda motor dengan membandingkan data kusioner dan data kecelakaan pada area perkotaan dan perdesaan. Penentuan area perkotaan dan perdesaan berdasarkan standar penilaian area oleh Biro Pusat Statistik (BPS) (2010). Penentuan kriteria ini berdasarkan evaluasi kepadatan penduduk, akses ke fasilitas umum, dan presentase rumah tangga pertanian. Penentuan area perkotaan dan perdesaan juga didukung oleh pemahaman akan area tinjauan seperti perkembangan penduduk dan kawasan yang mengalami perubahan fungsi seperti dari area pertanian menjadi kawasan perumahan

\section{ANALISA}

\section{Kecelakaan di Provinsi Sulawesi Utara}

Data kecelakaan berdasarkan area Polres di provinsi Sulawesi Utara adalah: 
Journal of Indonesia Road Safety - Vol. 2, No. 1, April 2019, p. 32-44

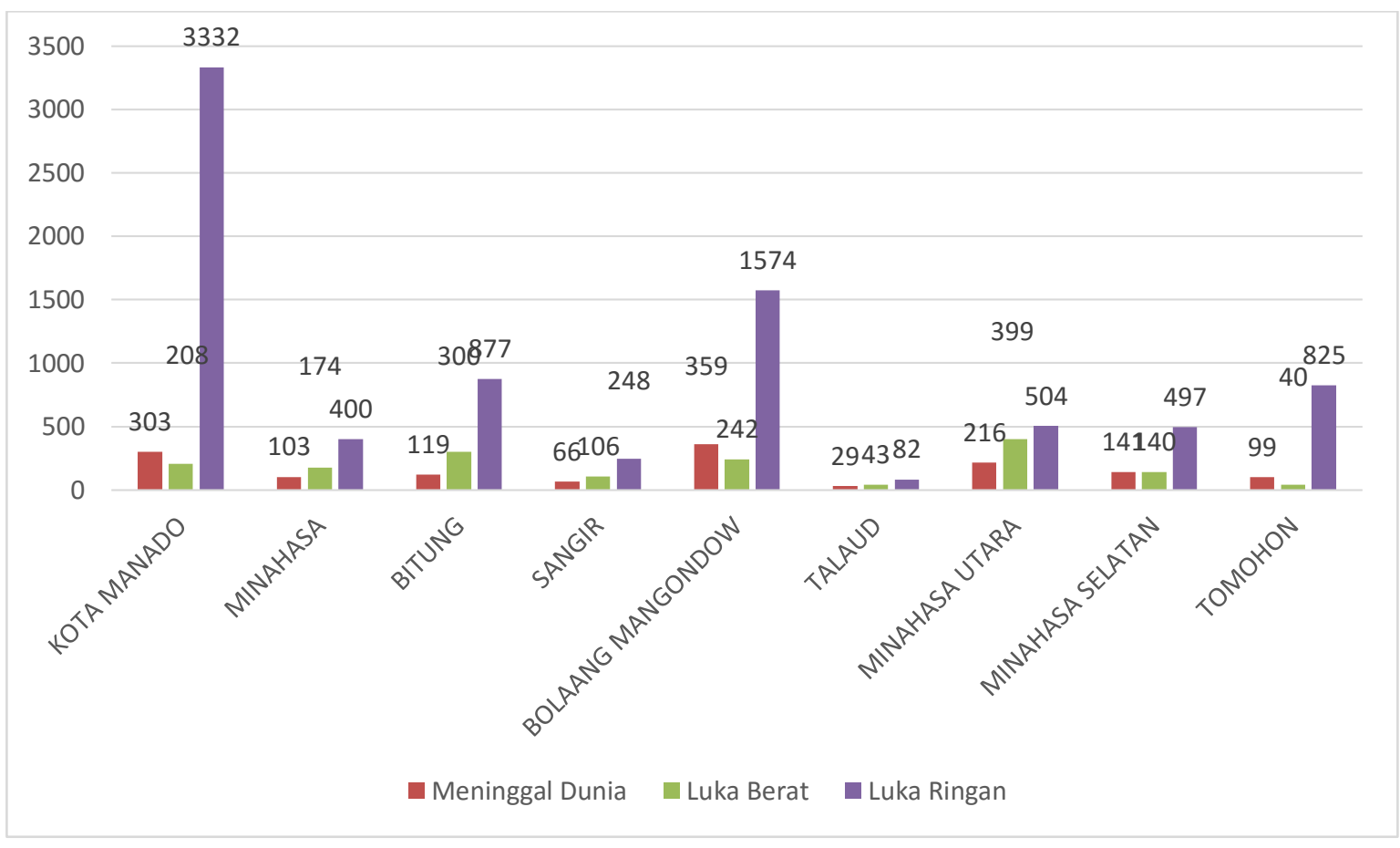

Gambar 1. Jumlah kecelakaan lalu lintas di Provinsi Sulawesi Utara menurut area Polres pada tahun $2014-2018$

Dari tabel di atas dapat dilihat bahwa kecelakaan terbanyak terdapat di kota Manado diikuti Kabupaten Bolaang Mangondow dan kabupaten Minahasa Utara.

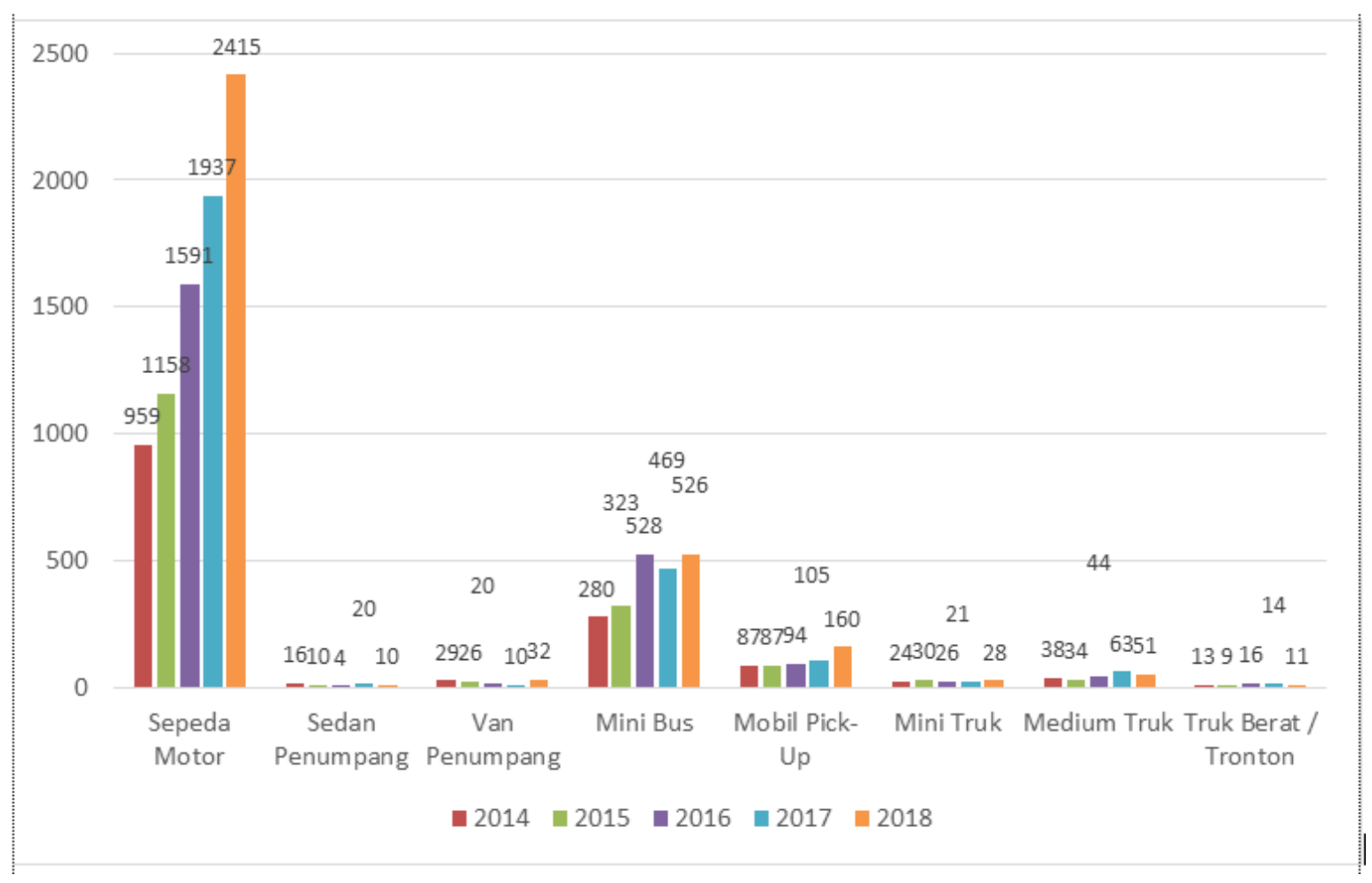

Gambar 2. Jumlah kecelakaan lalu lintas di Provinsi Sulawesi Utara menurut jenis kendaraan pada tahun $2014-2018$ 
Kecelakaan terbanyak dan meningkat tiap tahun adalah kecelakaan pengendara sepeda motor dengan jumlah total 8060 selama 5 tahun terakhir sejak 2014.

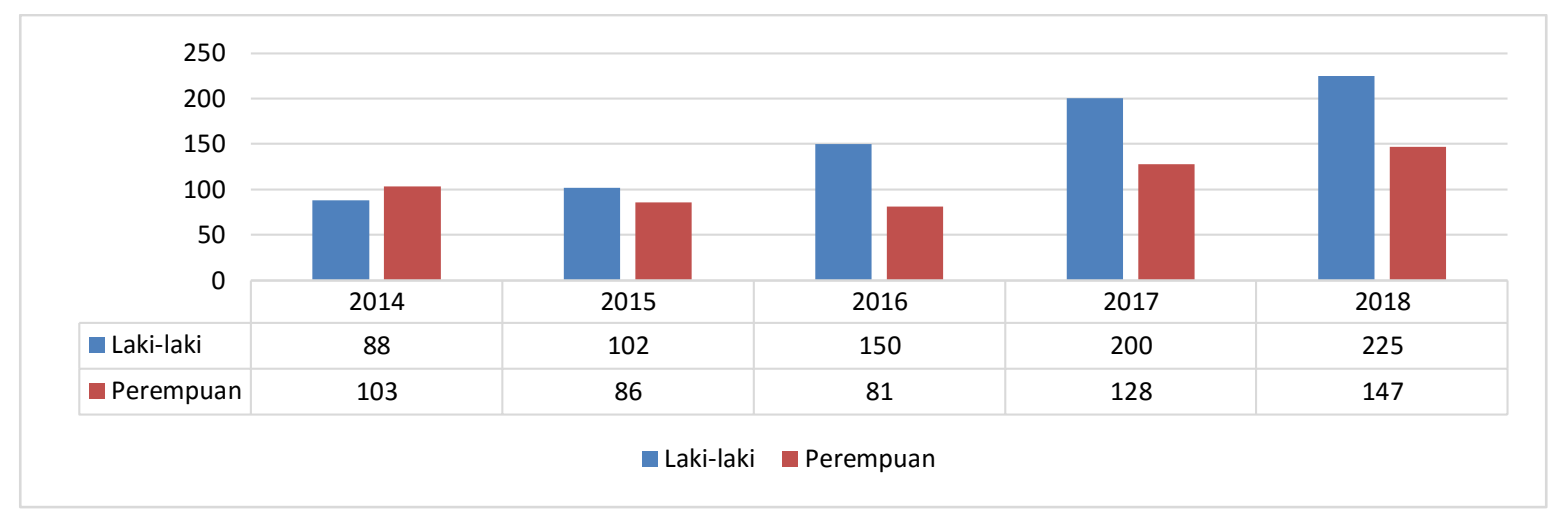

Gambar 3. Jumlah kecelakaan pejalan kaki di Provinsi Sulawesi Utara tahun 2014 - 2018

Jumlah kecelakaan pejalan kaki di provinsi Sulawesi Utara meningkat setiap tahunnya dengan perubahan dari 191 pejalan kaki di tahun 2014 menjadi 372 pejalan kaki di tahun 2018.

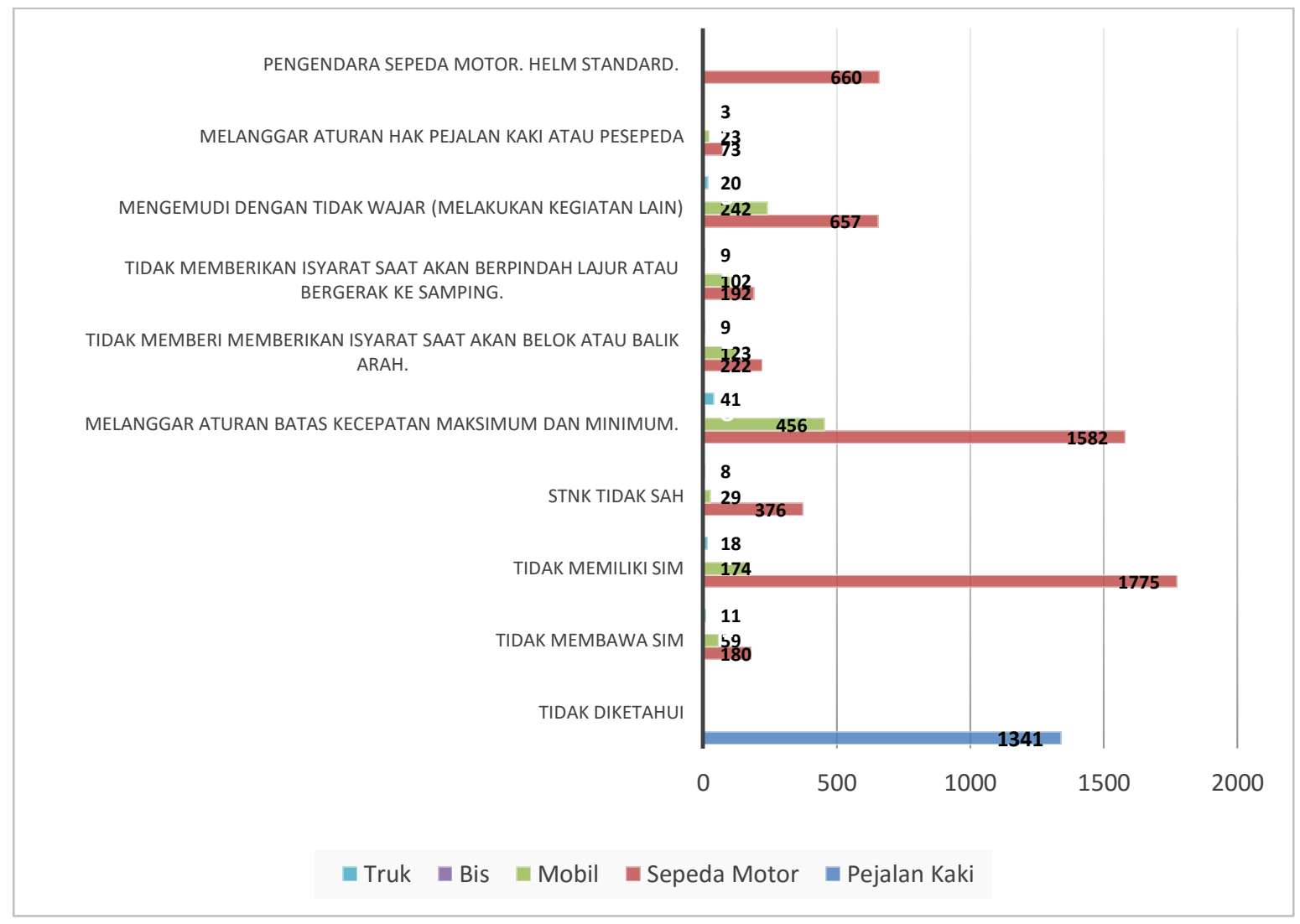

Gambar 4. Jumlah pelanggaran berdasarkan pengguna jalan di Provinsi Sulawesi Utara pada tahun $2014-2018$

Pelanggaran pengemudi kendaraan bermotor melanggar hak pejalan kaki dan pesepeda sebanyak 101 dengan mayoritas pengendara sepeda motor sebanyak 73 kejadian. 
Sementara pelanggaran sepeda motor terbanyak adalah tidak memiliki Surat Ijin Mengemudi (SIM) sebanyak 31\% dan melanggar batas kecepatan maksimum sebanyak 1582 pelanggaran atau $28 \%$ dari total pelanggaran.

Pelanggaran pengemudi kendaraan bermotor melanggar hak pejalan kaki dan pesepeda sebanyak 101 dengan mayoritas pengendara sepeda motor sebanyak 73 kejadian. Sementara pelanggaran sepeda motor terbanyak adalah tidak memiliki Surat Ijin Mengemudi (SIM) sebanyak 31\% dan melanggar batas kecepatan maksimum sebanyak 1582 pelanggaran atau $28 \%$ dari total pelanggaran.

\section{Karakteristik Pengendara Sepeda Motor}

Responden adalah pengendara sepeda motor di provinsi Sulawesi Utara yang memiliki SIM C dan atau banyak menggunakan sepeda motor dalam waktu setahun terakhir. Jumlah responden adalah 295 orang terdiri dari 246 tinggal di area perkotaan dan 49 tinggal di area perdesaan. Berdasarkan penilaian area perkotaan dan perdesaan (BPS, 2010) jumlah responden berasal dari area perkotaan terbanyak berasal dari kota Manado sebanyak 67,5\% dapat dilihat pada grafik di bawah ini.

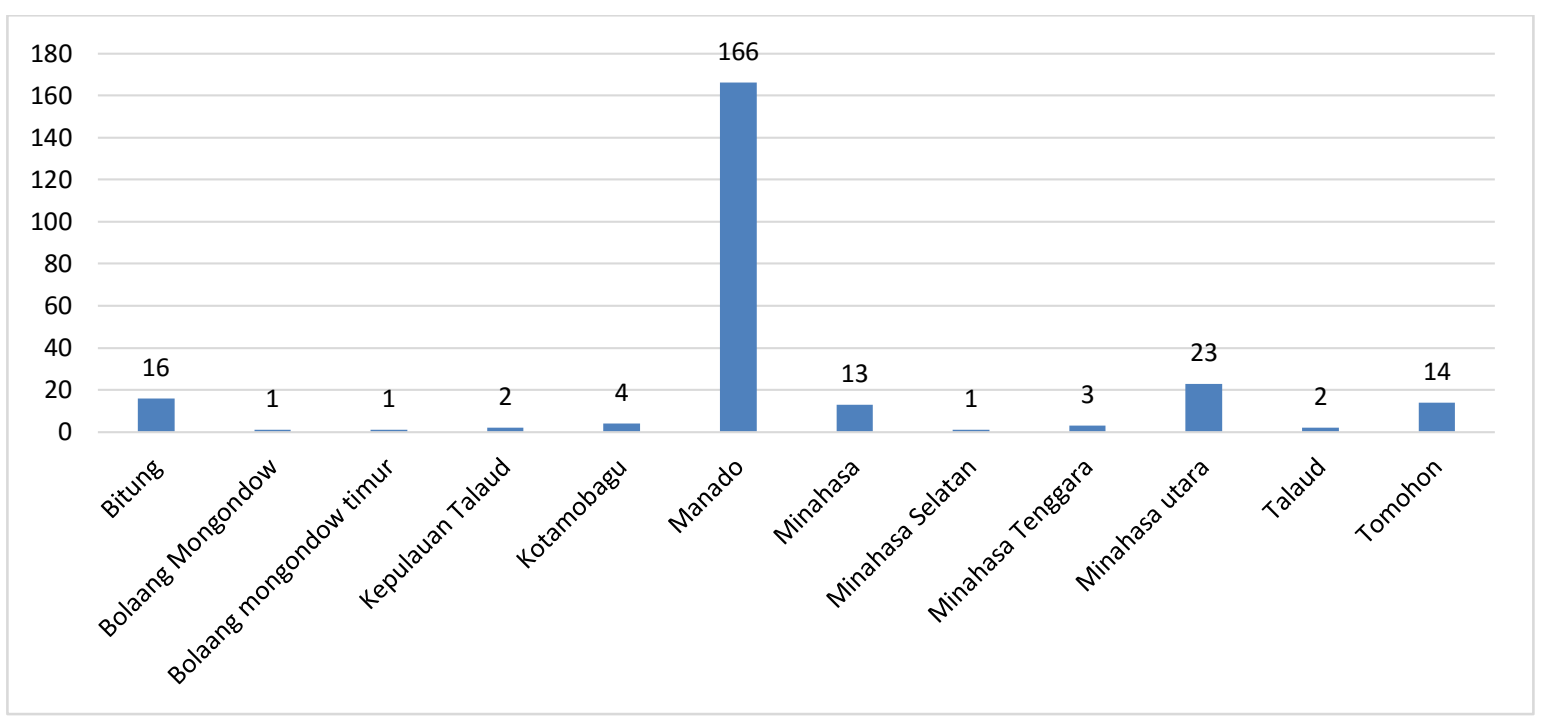

Gambar 5. Jumlah responden pengendara area perkotaan

Sedangkan responden dari area perdesaan dapat dilihat pada grafik di bawah ini. Jumlah responden terbanyak berasal dari Minahasa Selatan yaitu 24,5\%.

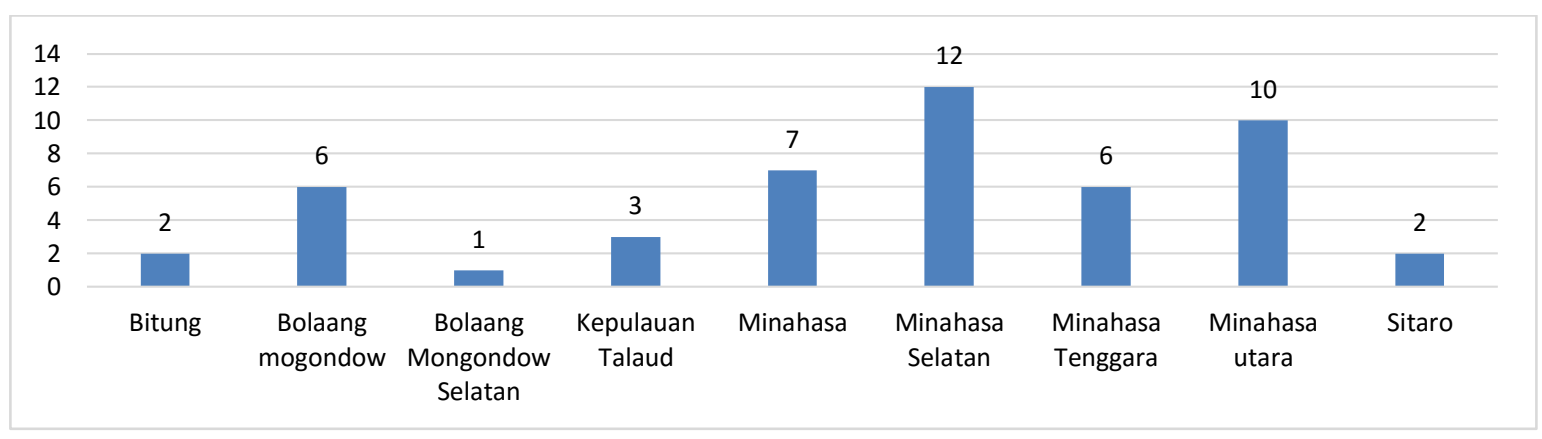

Gambar 6. Jumlah responden pengendara area perdesaan 
Tabel 1. Karakteristik reponden pengendara sepeda motor

\begin{tabular}{|c|c|c|c|c|}
\hline No & Karakteristik & Perkotaan & Perdesaan & Provinsi \\
\hline \multirow[t]{3}{*}{1} & Jenis kelamin & & & \\
\hline & Perempuan & 82 & 11 & 93 \\
\hline & Laki-laki & 164 & 38 & 202 \\
\hline \multirow[t]{3}{*}{2} & Usia & & & \\
\hline & $<25$ tahun & 146 & 35 & 181 \\
\hline & $>=25$ tahun & 95 & 13 & 108 \\
\hline \multirow[t]{7}{*}{3} & Pendidikan & & & \\
\hline & SMP & 4 & - & 4 \\
\hline & SMA & 146 & 34 & 180 \\
\hline & D3 & 8 & 1 & 9 \\
\hline & $\mathrm{S} 1$ & 75 & 11 & 86 \\
\hline & $\mathrm{S} 2$ & 11 & 1 & 12 \\
\hline & $\mathrm{S} 3$ & 2 & - & 2 \\
\hline \multirow[t]{5}{*}{4} & Lama mengemudi & & & \\
\hline & $<3$ tahun & 47 & 4 & 51 \\
\hline & $3-5$ tahun & 71 & 22 & 93 \\
\hline & $6-10$ tahun & 57 & 17 & 74 \\
\hline & $>10$ tahun & 71 & 6 & 77 \\
\hline 5 & $\begin{array}{l}\text { Mengalami kecelakaan pejalan kaki-sepeda } \\
\text { motor dalam } 1 \text { tahun terkahir }\end{array}$ & $\begin{array}{c}80 \\
(32,5 \%)\end{array}$ & $\begin{array}{c}15 \\
(30,6 \%)\end{array}$ & $\begin{array}{c}95 \\
(32 \%)\end{array}$ \\
\hline \multirow[t]{5}{*}{6} & Lokasi kecelakaan pejalan kaki-sepeda motor & & & \\
\hline & Jalan kebun & - & 1 & 1 \\
\hline & Jalan Raya & 75 & 17 & 92 \\
\hline & Kawasan dan kompleks & 3 & - & 3 \\
\hline & Trotoar & 8 & - & 8 \\
\hline
\end{tabular}

Berdasarkan karakteristik pengendara maka secara keseluruhan terdapat perbedaan dan persamaan antara pengendara area perkotaan dan perdesaan pada jumlah responden yang ditinjau. Persamaan dapat dilihat dalam hal jumlah yang lebih banyak adalah pengendara laki-laki, usia di bawah 25 tahun, Pendidikan Sekolah Menengah Atas dan presentase yang mengalami kecelakaan pejalan kaki-sepeda motor sekitar $30 \%$.

Sedangkan perbedaannya adalah lama mengendarai bagi pengendara di area perkotaan lebih banyak pengalaman mengendarai sepeda motor lebih dari 5 tahun sedangkan area perdesaan lebih banyak pengalaman dibawah 5 tahun. Selanjutnya tempat terjadinya kecelakaan di area perkotaan dan perdesaan didominasi oleh kecelakaan di jalan raya. Sedangkan perbedaan lokasi kecelakaan adalah di area perkotaan lokasi selain jalan raya adalah kompleks dan trotoar sedangkan di area perdesaan adalah di jalan kebun. 


\section{Penilaian Terhadap Fungsi Trotoar}

Tabel 2. Penilaian pengendara terhadap fungsi trotoar

\begin{tabular}{cccccc}
\hline No. & $\begin{array}{c}\text { Penilaian Pengendara Terhadap } \\
\text { Fungsi Trotoar }\end{array}$ & Pilihan & Perkotaan & Perdesaan & Provinsi \\
\hline 1. & Trotoar untuk pejalan kaki & S & 47,6 & 51,0 & 48,1 \\
& & SS & 50,4 & 42,9 & 49,2 \\
& & STS & 0,8 & 2,0 & 1,0 \\
\hline 2. & Trotoar untuk dilalui motor & TS & 1,2 & 4,1 & 1,7 \\
\hline & & S & 3,3 & 12,2 & 4,7 \\
\hline 3. & Trotoar untuk parkir motor & SS & 1,2 & 2,0 & 1,4 \\
\hline & & STS & 58,1 & 51,0 & 56,9 \\
\hline & & TS & 37,4 & 34,7 & 36,9 \\
\hline & & S & 4,1 & 22,4 & 7,1 \\
\hline
\end{tabular}

Secara keseluruhan pengendara di area perkotaan dan perdesaan setuju bahwa trotoar adalah untuk pejalan kaki dan bukan untuk dilalui oleh kendaraan sepeda motor dan untuk tempat parkir motor. Tetapi pengendara di area perdesaan dalam penilaian terhadap fungsi trotoar secara keseluruhan memiliki penilaian yang lebih kuat yang bertentangan dengan mayoritas pilihan. Meskipun presentase lebih sedikit dari pilihan mayoritas yang mengutamakan fungsi trotoar untuk pejalan kaki, tetapi adanya sejumlah pengendara yang setuju fungsi trotar untuk dilalui kendaraan dan tempat parkir menunjukkan pilihan untuk tidak mengutamakan keselamatan pejalan kaki dan memberi peluang untuk terjadi konflik yang dapat mengakibatkan kecelakaan antara pengendara dan pejalan kaki.

\section{Penilaian Terhadap Penyebab Kecelakaan}

Tabel 3. Penilaian pengendara terhadap penyebab kecelakaan

\begin{tabular}{|c|c|c|c|c|c|}
\hline No. & $\begin{array}{c}\text { Penilaian Pengendara Terhadap Penyebab } \\
\text { Kecelakaan }\end{array}$ & Pilihan & Perkotaan & Perdesaan & Provinsi \\
\hline \multirow[t]{4}{*}{1.} & \multirow{4}{*}{$\begin{array}{l}\text { Pengendara memiliki peran besar bila terjadi } \\
\text { kecelakaan dengan pejalan kaki }\end{array}$} & $\mathrm{S}$ & 57,3 & 63,3 & 58,3 \\
\hline & & $\mathrm{SS}$ & 13,4 & 6,1 & 12,2 \\
\hline & & STS & 6,1 & 14,3 & 7,5 \\
\hline & & $\mathrm{TS}$ & 23,2 & 16,3 & 22,0 \\
\hline \multirow[t]{4}{*}{2.} & \multirow{4}{*}{$\begin{array}{l}\text { Pengendara yang ngebut dapat meningkatkan } \\
\text { kecelakaan dengan pejalan kaki di trotoar } \\
\text { maupun jalan raya }\end{array}$} & $\mathrm{S}$ & 63,0 & 57,1 & 62,0 \\
\hline & & SS & 24,0 & 28,6 & 24,7 \\
\hline & & STS & 6,5 & 2,0 & 5,8 \\
\hline & & $\mathrm{TS}$ & 6,5 & 12,2 & 7,5 \\
\hline \multirow[t]{4}{*}{3.} & \multirow[t]{4}{*}{ Pejalan kaki harus memperhatikan motor } & $\mathrm{S}$ & 63,4 & 79,6 & 66,1 \\
\hline & & SS & 15,4 & 10,2 & 14,6 \\
\hline & & STS & 8,5 & 6,1 & 8,1 \\
\hline & & $\mathrm{TS}$ & 12,6 & 4,1 & 11,2 \\
\hline
\end{tabular}


Secara keseluruhan pengendara area perkotaan dan perdesaan setuju bahwa penyebab kecelakaan adalah pengendara, dengan perilaku ngebut. Tetapi juga pengendara setuju bahwa pejalan kaki harus memperhatikan kendaraan sepeda motor di area umum ketika berjalan kaki.

\section{Penilaian Terhadap Area Ramai Pejalan Kaki}

Tabel 4. Penilaian pengendara terhadap area ramai pejalan kaki

\begin{tabular}{|c|c|c|c|c|c|}
\hline No. & $\begin{array}{c}\text { Faktor Penilaian Pengendara Terhadap } \\
\text { Area Ramai Pejalan Kaki }\end{array}$ & Pilihan & Perkotaan & Perdesaan & Provinsi \\
\hline \multirow[t]{4}{*}{1.} & \multirow[t]{4}{*}{ Pengendara mendahulukan pejalan kaki } & S & 59,3 & 65,3 & 60,3 \\
\hline & & SS & 32,1 & 20,4 & 30,2 \\
\hline & & STS & 3,3 & - & 2,7 \\
\hline & & $\mathrm{TS}$ & 5,3 & 14,3 & 6,8 \\
\hline \multirow[t]{4}{*}{2.} & \multirow{4}{*}{$\begin{array}{l}\text { Pengendara menggunakan perlengkapan } \\
\text { mengemudi yang lengkap }\end{array}$} & S & 57,3 & 69,4 & 59,3 \\
\hline & & SS & 36,2 & 28,6 & 34,9 \\
\hline & & STS & 1,6 & - & 1,4 \\
\hline & & TS & 4,9 & 2,0 & 4,4 \\
\hline \multirow[t]{4}{*}{3.} & \multirow{4}{*}{$\begin{array}{l}\text { Kondisi kendaraan sepeda motor harus } \\
\text { memiliki rem dan lampu yang berfungsi } \\
\text { dengan baik }\end{array}$} & $S$ & 57,7 & 63,3 & 58,6 \\
\hline & & SS & 38,6 & 34,7 & 38,0 \\
\hline & & STS & 1,2 & - & 1,0 \\
\hline & & $\mathrm{TS}$ & 2,4 & 2,0 & 2,4 \\
\hline \multirow[t]{4}{*}{4.} & \multirow{4}{*}{$\begin{array}{l}\text { Rambu lalu lintas untuk pejalan kaki harus } \\
\text { jelas }\end{array}$} & S & 59,3 & 59,2 & 59,3 \\
\hline & & SS & 37,8 & 36,7 & 37,6 \\
\hline & & STS & 1,2 & - & 1,0 \\
\hline & & $\mathrm{TS}$ & 1,6 & 4,1 & 2,0 \\
\hline \multirow[t]{4}{*}{5.} & \multirow[t]{4}{*}{ Area penyeberangan harus ditandai } & S & 56,1 & 55,1 & 55,9 \\
\hline & & SS & 40,7 & 40,8 & 40,7 \\
\hline & & STS & 1,2 & - & 1,0 \\
\hline & & $\mathrm{TS}$ & 2,0 & 4,1 & 2,4 \\
\hline
\end{tabular}

Pada area yang ramai pejalan kaki secara kseluruhan pengendara setuju bahwa pejalan kaki harus didahulukan, pengendara menggunakan perlengkapan mengendarai, kondisi kendaraan harus baik. Tetapi pengendara juga setuju bahwa rambu lalu lintas harus jelas dan area penyeberangan harus ditandai. 
Tabel 5. Evaluasi faktor pengaruh perilaku pengendara area perkotaan dan perdesaan

\begin{tabular}{|c|c|c|c|c|}
\hline No & Faktor & Mayoritas & Pilihan & $\begin{array}{c}\text { Lebih } \\
\text { Tinggi } \\
\text { Presentase }\end{array}$ \\
\hline 1 & Trotoar untuk pejalan kaki & $\begin{array}{l}\text { Setuju dan sangat } \\
\text { setuju }\end{array}$ & $\begin{array}{c}\text { Sangat Tidak } \\
\text { Setuju (STS) dan } \\
\text { Tidak Setuju (TS) }\end{array}$ & Perdesaan \\
\hline 2 & Trotoar untuk dilalui motor & $\begin{array}{l}\text { Sangat tidak setuju } \\
\text { dan tidak setuju }\end{array}$ & Setuju (S) & Perdesaan \\
\hline 3 & Trotoar untuk parkir motor & $\begin{array}{l}\text { Sangat tidak setuju } \\
\text { dan tidak setuju }\end{array}$ & $S$ & Perdesaan \\
\hline 4 & $\begin{array}{l}\text { Pejalan kaki harus memperhatikan } \\
\text { motor }\end{array}$ & $\begin{array}{l}\text { Setuju dan sangat } \\
\text { setuju }\end{array}$ & $\mathrm{TS}$ & Perkotaan \\
\hline \multirow[t]{2}{*}{5} & \multirow{2}{*}{$\begin{array}{l}\text { Pengendara memiliki peran besar bila } \\
\text { terjadi kecelakaan dengan pejalan kaki }\end{array}$} & \multirow{2}{*}{$\begin{array}{l}\text { Setuju dan sangat } \\
\text { setuju }\end{array}$} & $\mathrm{TS}$ & Perkotaan \\
\hline & & & STS & Perdesaan \\
\hline 6 & $\begin{array}{l}\text { Pengendara yang ngebut dapat } \\
\text { meningkatkan kecelakaan dengan } \\
\text { pejalan kaki di trotoar maupun jalan } \\
\text { raya }\end{array}$ & $\begin{array}{l}\text { Setuju dan sangat } \\
\text { setuju }\end{array}$ & $\mathrm{TS}$ & Perdesaan \\
\hline 7 & Pengendara mendahulukan pejalan kaki & $\begin{array}{l}\text { Setuju dan sangat } \\
\text { setuju }\end{array}$ & $\begin{array}{c}\mathrm{TS} \\
\mathrm{STS}=0\end{array}$ & Perdesaan \\
\hline \multirow[t]{2}{*}{8} & \multirow{2}{*}{$\begin{array}{l}\text { Pengendara menggunakan perlengkapan } \\
\text { mengemudi yang lengkap }\end{array}$} & \multirow{2}{*}{$\begin{array}{l}\text { Setuju dan sangat } \\
\text { setuju }\end{array}$} & $\mathrm{TS}$ & Perkotaan \\
\hline & & & $\mathrm{STS}=0$ & Perdesaan \\
\hline 9 & $\begin{array}{l}\text { Kondisi kendaraan sepeda motor harus } \\
\text { memiliki rem dan lampu yang berfungsi } \\
\text { dengan baik }\end{array}$ & $\begin{array}{l}\text { Setuju dan sangat } \\
\text { setuju }\end{array}$ & $\mathrm{STS}=0$ & Perdesaan \\
\hline 10 & $\begin{array}{l}\text { Rambu lalu lintas untuk pejalan kaki } \\
\text { harus jelas }\end{array}$ & $\begin{array}{l}\text { Setuju dan sangat } \\
\text { setuju }\end{array}$ & $\begin{array}{c}\mathrm{TS} \\
\mathrm{STS}=0\end{array}$ & Perdesaan \\
\hline 11 & Area penyeberangan harus ditandai & $\begin{array}{l}\text { Setuju dan sangat } \\
\text { setuju }\end{array}$ & $\begin{array}{c}\mathrm{TS} \\
\mathrm{STS}=0\end{array}$ & Perdesaan \\
\hline
\end{tabular}

Tingginya presentase pengendara terhadap pilihan yang mengutamakan keselamatan pejalan kaki dan pengendara menunjukkan perlunya dukungan terhadap fasilitas pengendara. Jalur pejalan kaki khusus untuk pejalan kaki sehingga perlu adanya jalur khusus untuk sepeda motor untuk jalan bila memungkinkan. Lebar jalur sepeda motor perlu diperhitungkan demikian juga penentuan kecepatan kendaraan. Sehingga jalur pejalan kaki tidak digunakan oleh pengendara. Demikian juga harapan pengendara agar jalur pejalan kaki memiliki rambu dan tanda penyeberangan dan pejalan kaki agar memperhatikan sepeda motor menunjukkan pemahaman terhadap kelengkapan fasilitas jalan yang dapat mengurangi kemungkinan konflik sepeda motor dan pejalan kaki dan mengurangi terjadinya kecelakaan. Kecepatan sepeda motor yang jauh lebih tinggi dari kendaraan lain dan jumlah yang lebih banyak membutuhkan penanganan manajemen lalu lintas sepeda motor didukung pleh perencanaan area yang tepat. Pada penilaian pengendara untuk area yang ramai pejalan kaki di perkotaan dan perdesaan terlihat bahwa pilihan sangat tidak setuju memiliki presentase 0\%. Bila dilihat bahwa kecelakaan trotoar tidak terjadi di area perdesaan dengan karakteristik jalan perdesaan yang sebagian besar tidak 
memiliki trotoar dan memiliki kepadatan penduduk yang rendah maka penilaian ini sesuai. Tetapi pilihan ini juga dapat menunjukkan bahwa pengendara di area perdesaan lebih mengutamakan keselamatan pejalan kaki di banding area perkotaan.

\section{Forum Group Discussion (FGD)}

Pada kegiatan Focus Group Discussion (FGD) Provinsi Sulawesi Utara hadir tim Dirlantas Polda Sulut, masyarakat pengendara sepeda motor, dosen, mahasiswa dan peneliti. Informasi dari dirlantas mengenai faktor penyebab kecelakaan adalah pengendara dan kondisi jalan. Usulan dari tim dirlantas Polda Sulut juga perlu adanya rambu lalu lintas. Kegiatan FGD ini juga mendiskusikan usulan-usulan berkaitan dengan kecelakaan pejalan kaki-pengendara sepeda motor. Mahasiswa peneliti masalah pejalan kaki membahas bahwa bagi area yang ramai pejalan kaki seperti kawasan Bahu Mall Manado, yang menjadi area penelitian mereka, perlu peraturan yang jelas untuk area trotoar bagi pejalan kaki dan bukan untuk parkir motor. Hal ini disebabkan pejalan kaki berpindah menggunakan jalur jalan yang membahayakan keselamatan mereka. Usulan dari masyarakat pengendara yang juga memiliki pengalaman mengendarai sepeda motor di area perdesaan dan perkotaan adalah untuk jalur pejalan kaki perlu adanya jembatan penyeberangan orang (JPO) di area pusat kota yang ramai kendaraan seperti di area zero-point kota Manado serta daerah lampu lalu lintas perlu ada tanda untuk penyeberangan. Trotoar tidak dijadikan tempat parkir motor. Menurut pengendara, di area perdesaan, petugas kepolisian jumlahnya sedikit sehingga penanganan penyebab kecelakaan kurang tertangani dengan baik. Selanjutnya usulan pengendara yang banyak mengendarai sepeda motor di area perkotaan mengusulkan agar rambu-rambu lalu lintas dan zebra cross perlu diperjelas terutama area yang tanda penyeberangannya sudah mulai pudar. Hal ini untuk menghindari kecelakaan antara pengendara dan pejalan kaki

\section{KESIMPULAN}

Evaluasi penilaian pengendara sepeda motor untuk mengurangi kecelakaan pejalan kakisepeda motor menunjukkan persamaan dan perbedaan di area perkotaan dan perdesaan. Melalui penilaian pengendara terlihat bagaimana pengaruh perilaku pengendara terhadap faktor penyebab kecelakaan. Pemahaman terhadap fungsi trotoar sebagai jalur pejalan kaki dan bukan untuk jalur lalu lintas dan parkir sepeda motor menunjukkan sikap pengendara untuk menghindari konflik yang mengakibatkan kecelakaan. Di lain pihak pengendara juga mengharapkan pejalan kaki untuk memperhatikan kendaraan saat berjalan kaki. Aspekaspek yang diharapkan pengendara terhadap pemenuhan fasilitas pejalan kaki dan kelengkapan sepeda motor dapat membantu mengurangi kecelakaan. Demikian pula faktor mengendarai melebihi kecepatan diakui menyebabkan kecelakaan pejalan kaki-sepeda motor. Perbedaan penilaian pengendara area perkotaan dan perdesaan ditentukan oleh faktor pejalan kaki dan pengendara serta kondisi jalur yang tersedia. Akan tetapi perlu dilakukan penelitian lebih lanjut untuk mengetahui alasan penilaian yang menentang tindakan untuk keselamatan pejalan kaki seperti keberadaan jalur pejalan kaki di area perdesaan dan pengaruh perilaku pejalan kaki pada peningkatan kecelakaan pejalan kakisepeda motor. 


\section{PEMANFAATAN UNTUK KEPOLISIAN LALULINTAS}

Manfaat penelitian bagi kepolisian laulintas adalah menjadi bahan acuan dalam membuat kebijakan bagi pengendara sepeda motor dan pejalan kaki baik dalam hal persyaratan pengendara, peraturan lalu lintas pada jalur jalan serta peningkatan rambu-rambu lalu lintas yang menjamin keselamatan pengguna jalan.

\section{UCAPAN TERIMA KASIH}

Tim peneliti TARC provinsi Sulawesi Utara mengucapkan terima kasih kepada Pihak Korlantas POLRI yang memberikan dana hibah penelitian keselamatan dan akses terhadap data kecelakaan nasional IRSMS. Demikian juga kepada tim Dirlantas Polda Sulut yang membantu memberikan data dan informasi berkaitan dengan kecelakaan pejalan kakisepeda motor.

\section{DAFTAR PUSTAKA}

Ariffin, Aqbal Hafeez., Hamzah, Azhar., Solah, Mohd Syazwan, Paiman, Noor Faradila, Hussin, Siti Fairos Mat and Osman, Mohd Rasid (2017), Pedestrian-Motorcycle Collisions: Associated Risks and Issues, (2017) DOI: 10.1051/ 79001066, MATEC

Bella, Francesco, Calvi, Alessandro, D’Amico, Fabrizio (2012), SIIV - 5th International Congress - Sustainability of Road Infrastructures Impact of Pavement Defects on Motorcycles' Road Safety, Procedia - Social and Behavioral Sciences 53943 - 952

Chen, Zhen and Fan, Wei (David) (2019), A multinomial logit model of pedestrian-vehicle crash severity in North Carolina, International Journal of Transportation Science and Technology 8 43-52

Cheng, Andy S.K., Liu, Karen P.Y. and Tulliani, Nikki (2015), Relationship Between Driving-violation Behaviours and Risk Perception in Motorcycle Accidents, Hong Kong Journal of Occupational Therapy 25, 32e 38

Demir, Basar., Özkan, Türker, and Demir, S1la (2019), Pedestrian violations: Reasoned or social reactive? Comparing theory of planned behavior and prototype willingness model, Transportation Research Part F 60 560-572

Eiksund, Syeinung (2009), A Geographical Perspective On Driving Attitudes And Behaviour Among Young Adults In Urban And Rural Norway, Safety Science 47(4):529-536

Finch, D.J., Kompfner P., Lockwood C.R and Maycock, G (1994), Speed, speed limit and accidents, Safety Resource centre Transport research laboratory

Hussain H., Radin, Umar R.S., Ahmad, Farhan M.S. and, Dadang M.M.(2005), Key Components Of A Motorcycle-Traffic System - A Study Along The Motorcycle Path In Malaysia - IATSS Research Vol.29 No.1, 2005

Indriani, Dini dan Yulianti, Kunthi (2015), Pola Luka Korban Kecelakaan Lalu Lintas pada Pejalan Kaki Dan Pengendara Sepeda Motor, E-Jurnal Medika Udayana Vol 4 No 8

Le, To Quyen and Nurhidayati, Zuni Asih (2016), A Study of Motorcycle Lane Design in Some Asian Countries, Sustainable Development of Civil, Urban and Transportation Engineering Conference, Procedia Engineering 142292 - 298 
Machin, M.A., and Sankey, K.S (2008) Relationship between young driver's personal characteristics, risk perception and driving behavior, Accident Analysis \& Prevention 40 (2), 541-547

Motevalian, Seyed Abbas., Asadi-Lari, Mohsen, Rahimi, Habibollah and Eftekhar, Mehrdad, (2011), Validation of a Persian Version of Motorcycle Rider Behaviour Questionnaire, $5^{\text {th }}$ AAAM Annual Conference, Annals of Advances in Automotive Medicine, October 3 - 52011

Solagberu, B A., Ofoegbu, C K P., Nasir, A A., Ogundipe, O K., Adekanye, A O., AbdurRahman, L O (2006), Motorcycle injuries in a developing country and the vulnerability of riders, passengers, and pedestrians, Injury Prevention 2006;12:266268.

Wong, Jinn-Tsai., Chung, Yi-Shih and Huang, Shih-Hsuan (2010) Determinants Behind Young Motorcyclists' Risky Riding Behavior, Accident Analysis and Prevention 42 275-281 